\title{
Analysis on the Current State of the Disney Economy and Sentiment Text Analysis on Customer Reviews
}

\author{
Siping Ren ${ }^{1, *}$ \\ ${ }^{1}$ Central China Normal University, Wuhan, Hubei, China \\ *Corresponding author. Email: renaissance990831@outlook.com
}

\begin{abstract}
The first part of this paper is a data analysis of Disney's economic situation, starting with an analysis of the company's overall assets, followed by an analysis of the economic direction of the four areas under Disney, and finally an investor's perspective on Disney's development trends. The specific indicators analyzed are operating income, net income, total assets, total liabilities, earnings per share, etc. The second part is based on the word frequency statistics of the evaluation text of Disneyland by different groups of ratings, and the cloud chart can more visually show the difference of the evaluation between different groups. Disney's unique economic composition makes it quite different from traditional media companies, and exploring Disney's economic growth model has significant implications for the development of future media companies. The purpose of this paper is to improve the service through exploring the current economic situation of Disney, visualizing and analyzing the visitor evaluation of the Disney theme park, which is the largest module of Disney's business. The theme parks account for the largest share of Disney's four economic modules, but revenues in this area have been significantly affected by the epidemic; the results of the analysis of its visitor evaluations clearly point out the strengths and weaknesses of its services and serve to provide recommendations for its development.
\end{abstract}

Keywords: Disney, Economic status, Text analysis, Word frequency statistics.

\section{INTRODUCTION}

The Disney Company (Disney) is a century-old company in the American media industry and a well-known company in the global entertainment industry. Disney and its subsidiaries are a global diversified entertainment company and ranked seventh in the Forbes Global Brand Value 100 in July 2020 [1]. Although Disney started with film and television and became famous with film and television, but now film and television entertainment is no longer its main source of interest, film and television entertainment to establish a good IP image, and then around the film and television derived from the peripheral products have become an economic force that cannot be ignored [2]. In an era of media change, Disney has not stuck to the old ways, but has actively innovated and sought business breakthroughs, opening up new space for development in areas such as online video business [3]. Disney's economic development model has set a good example for our entertainment industry today, and how to better develop in multiple directions and angles in the new era has been an increasingly important issue for entertainment companies to pay attention to few relevant studies on Disney services [5].

This paper will analyze Disney's current economic data in various areas as well as a review text based on the theme park to see if it can provide suggestions for its development [6].

\section{BACKGROUND OF DISNEY}

Corporate Businesses and Sources of Interest: The Group's businesses are aligned into four major segments: Media Networks, Theme Parks/Experiences \& Consumer Products, Filmed Entertainment, and DTCI. 
Media Networks consist of five major businesses: Disney, ESPN, Freeform, FX and National Geographic domestic cable networks; ABC Radio Networks and eight domestic television stations; television production and distribution; National Geographic; and $\mathrm{A}+\mathrm{E}$ Television Networks. Media Networks business segment revenues derived primarily from: membership fees (charged to video program distributors, television stations, etc.), advertising fees (television station advertising and online platform advertising), television program royalties and other revenues.

Theme Parks, Experiences and Consumer Products consist of two main businesses: Theme Parks and Resorts (including the various Disney Parks, Disney Resorts, Disney Vacation Clubs, Disney Cruise Line, Disney Adventure, National Geographic Adventure, etc. operated directly by the Group; Tokyo Disney Resort, etc. operated under license to third parties), and Licensing and Retail (licensing business - licensing of trade names, characters, visual, literary and other intellectual property rights to manufacturers, game developers, publishers and retailers worldwide; retail business offline and online retail/wholesale sales of branded merchandise, development and publication of books, comic books and magazines, etc.).

The segment's business revenues are derived from: sales of theme park tickets/food/drink and merchandise, fees for vacations and vacation packages (including hotels, cruise ship rentals, etc.), royalties from Tokyo Disney Resort; licensing fees for merchandise intellectual property, merchandising (sales of merchandise through Disney Stores, online platforms, wholesalers, etc.), sponsorship and co-branding, etc.

Film \& TV Entertainment consists of four main businesses: production and distribution of motion pictures (which includes film companies: Walt Disney Pictures, 21st Century Fox, Marvel Studios, Lucasfilm, Pixar Films, etc.), development and production of stage productions (Broadway and worldwide), production and distribution of music, and post-production services. The Film and Entertainment segment derives its primary revenues from: film distribution, home entertainment (sales of DVDs and Blu-rays), TV / SVOD distribution and others (TV and streaming screening rights, ticket sales for stage productions, rights to musical productions, fees for post-production services, etc.).

DTCI is short for direct-to-consumer business, and international business segment and contains four main businesses: branded international television networks and channels (including Disney, ESPN, Fox, National Geographic, Star International), direct-to-consumer streaming services (including Disney +, ESPN +, Hotstar, Hulu), other digital content distribution platforms and services, and equity investments.

DTCI business segment revenues are derived from: membership fees, advertising, subscription fees for streaming and other services, fees for technical support services, etc.

\section{DATA ANALYSIS}

\subsection{The Overall Picture of the Disney Economy}

There are four indicators for judging the overall economy of Disney, of which I have selected operating income and net income/total assets and total liabilities/net cash flow from operating activities/EPS to describe the current overall economic situation, and these indicators are commonly used in measuring business operations.

\subsection{The Relationship Between These Indicators}

Net profit is the end result of business operations and is the main indicator of business efficiency.

Operating income management is an important aspect of enterprise financial management, which is related to the survival and development of the enterprise.

Net profit is the basis of expected future cash flow, and the degree of difference between cash flow and net profit can reveal the quality of net profit.

The balance sheet is one of the three main financial statements of an enterprise, and it is extremely important for a rational or potential investor to analyze the balance sheet of an enterprise in order to properly evaluate the financial position and solvency of the enterprise.

Earnings per share is usually used to reflect the operating results of an enterprise, to measure the profitability level of common shares and investment risks, and is one of the important financial indicators for investors and other information users to evaluate the profitability of an enterprise, predict its growth potential and make relevant economic decisions. 


\subsubsection{Operating Revenue and Net Profit}

Operating revenue is the total inflow of economic benefits formed by an enterprise in the course of its daily business operations, such as selling goods, providing services and transferring the right to use assets.

Net profit is the final result of an enterprise's operation. If there is more net profit, the operating efficiency of the enterprise is good; if there is less net profit, the operating efficiency of the enterprise is poor, and it is the main indicator to measure the operating efficiency of an enterprise. Net profit is a very important economic indicator. For the investors of the enterprise, net profit is the basic factor to get the size of investment return, and for the managers of the enterprise, net profit is the basis to make business management decisions. At the same time, net profit is also a basic tool to evaluate the profitability, management performance and solvency of an enterprise, and is a comprehensive indicator to reflect and analyze various aspects of an enterprise.

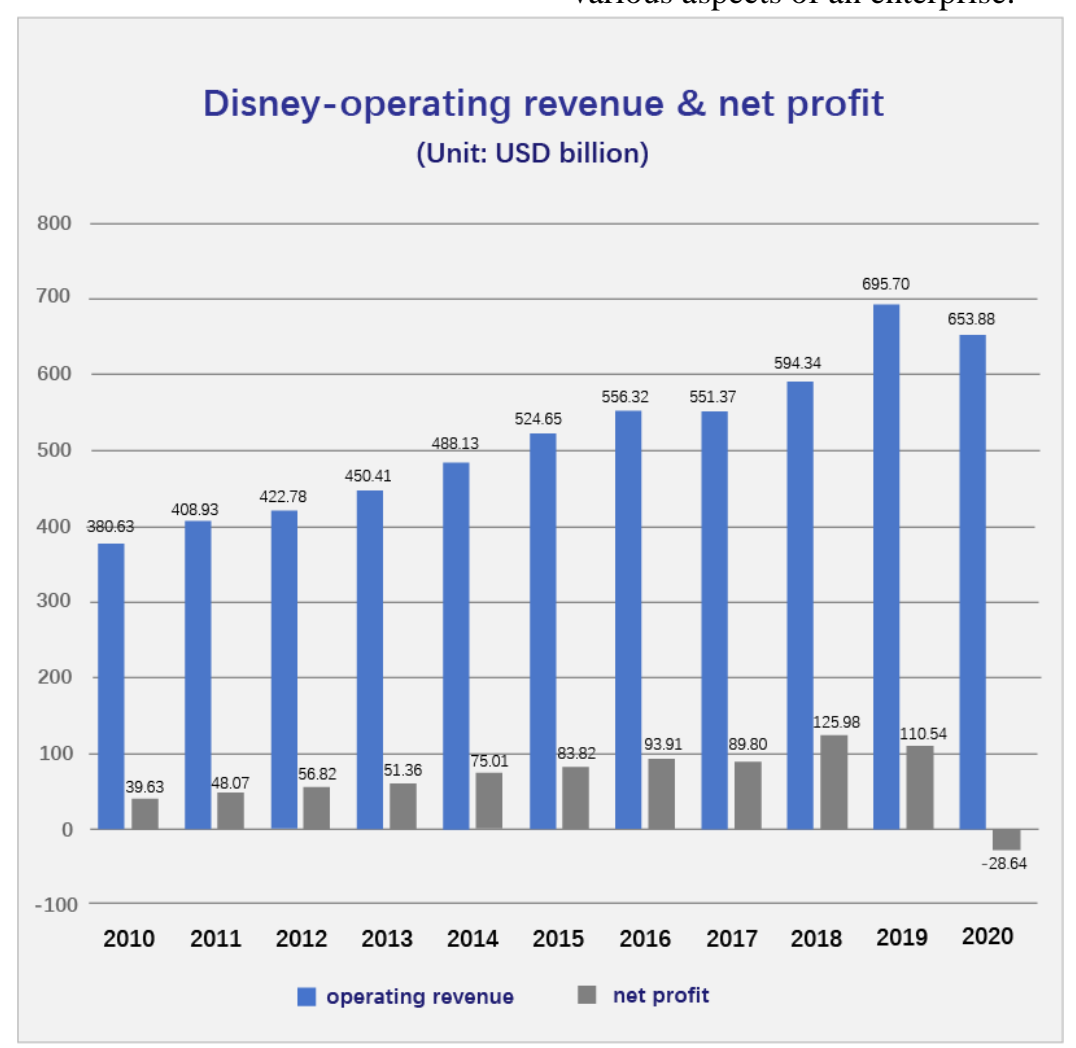

Figure 1 Operating revenue and net profit of Disney.

From Figure1, Disney's revenue and profit increased year over year overall, with a slight decline in 2017 and a significant increase in revenue but a decline in profit in 2019 . It is worth noting that in 2020 profits were negative for the first time since 2010 due to the impact of the epidemic.

\subsubsection{Net Cash Flow from Three Major Categories}

In the statement of cash flows, cash flows are classified into three major categories: net cash flows from operating activities, net cash flows from investing activities, and net cash flows from financing activities.
Operating activities directly involve the production of products, sale of goods or provision of services, and are the main transactions and events from which an enterprise obtains revenue.

Investing activities refer to the construction of fixed assets and investment activities within the scope of excluding cash equivalents and their disposal.

Financing activities result in changes in the size and composition of the enterprise's capital and debt.

In the development of modern enterprises, it is cash flow that determines the demise of an enterprise, and it is cash flow that best reflects the essence of an enterprise, and the evaluation based 
on cash flow is the most authoritative among many evaluation indicators.

Cash flow is a better indicator of the quality of an enterprise's profitability than traditional profit indicators. First of all, to address the shortcomings of using non-operating activities such as increasing investment income to manipulate profits, cash flow only calculates operating profit and excludes nonrecurring income. Second, accounting profit is determined on an accrual basis, and can be adjusted by fraudulent sales, early recognition of sales, expansion of credit sales or related transactions, while cash flow is determined on a cash basis, and appeals to adjust profit cannot be made to obtain cash and therefore cannot increase cash flow. It can be seen that the cash flow indicator can compensate for the shortcomings of the profit indicator in reflecting the true profitability of the company.

\section{Net cash flow from three aspects (Unit: USD)}

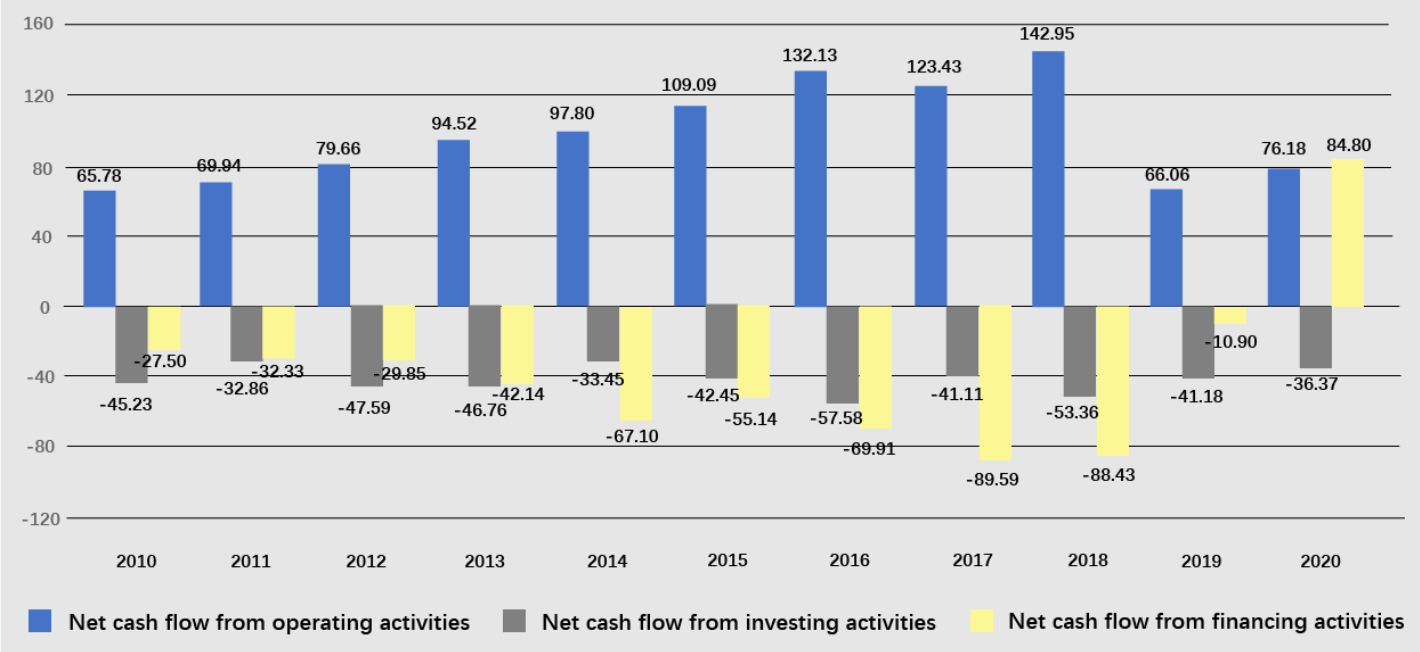

Figure 2 Net cash flow from three major categories of Disney.

It can be seen from Figure 2 that although the financing cash flow and investment cash flow have been negative for a long time, the operating cash flow is relatively solid, which indicates that TWDC is running relatively well and its main business is relatively clear. There is a significant increase in financing cash flow in 2020, which indicates that the company is incorporating a large amount of capital, possibly for a new project or bond issue. Although Disney has been hit hard by the epidemic, there is a very good chance that it will weather this one smoothly.

\subsubsection{Total Assets and Total Liabilities}

Total assets are all the assets of dao owned or controlled by an economic bai entity du that can bring economic benefits.

Total liabilities are all the debts assumed by an enterprise and need to be repaid, including current liabilities and long-term liabilities, deferred taxes, etc., that is, the total liabilities of the enterprise balance sheet. 


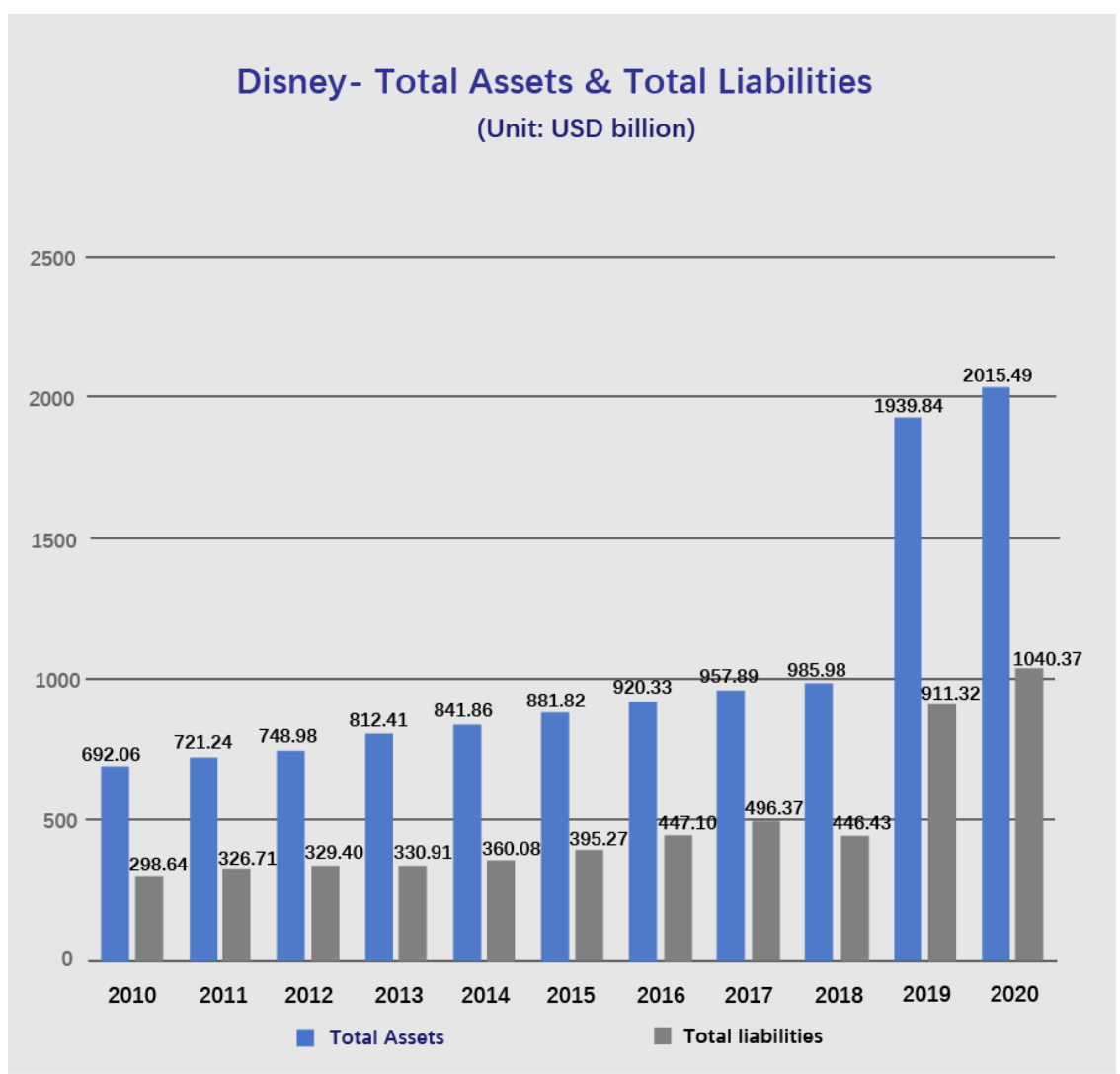

Figure 3 Total assets and total liabilities of Disney.

From Figure 3, it can be seen from this that Disney's total assets and total liabilities are both growing, reaching a maximum for both in 2020. In 2019 total assets and total liabilities both nearly doubled. The growth trend for both is more moderate until 2019. Between 2010 and 2020 total assets are almost twice as high as total liabilities.

\subsubsection{EPS}

Earnings per share (EPS), also known as profit after tax per share and earnings per share, refers to the ratio of profit after tax to total equity. It is the net profit or net loss of the enterprise that common shareholders are entitled to per share held. It is one of the most important financial indicators for investors and other information users to evaluate the profitability of a company, forecast its growth potential and make relevant economic decisions.

It was an upward trend until 2017, reaching the highest EPS in 2018. We can find that in 2019 EPS has seen a decline, and in 2020 it is negative for the first time, which shows the magnitude of the impact of the epidemic on Disney.

\section{DIFFERENCES IN REVENUE FROM DIFFERENT PARTS OF DISNEY - A COMPARATIVE ANALYSIS OF THE DIFFERENT SOURCES OF DISNEY REVENUE}

\subsection{To Analyze the Different Revenue Scenarios of Disney}

The data shows that it is still the Disney-related service industry that accounts for the vast majority of the revenue components.

\section{2 (Total) Revenue Data from Different Disney Locations}

The main revenue region is still the Americas, followed by Europe and finally Asia. However, the Asian market is a place worth developing, especially for film and TV and theme parks (along with the development of Shanghai Disney). 


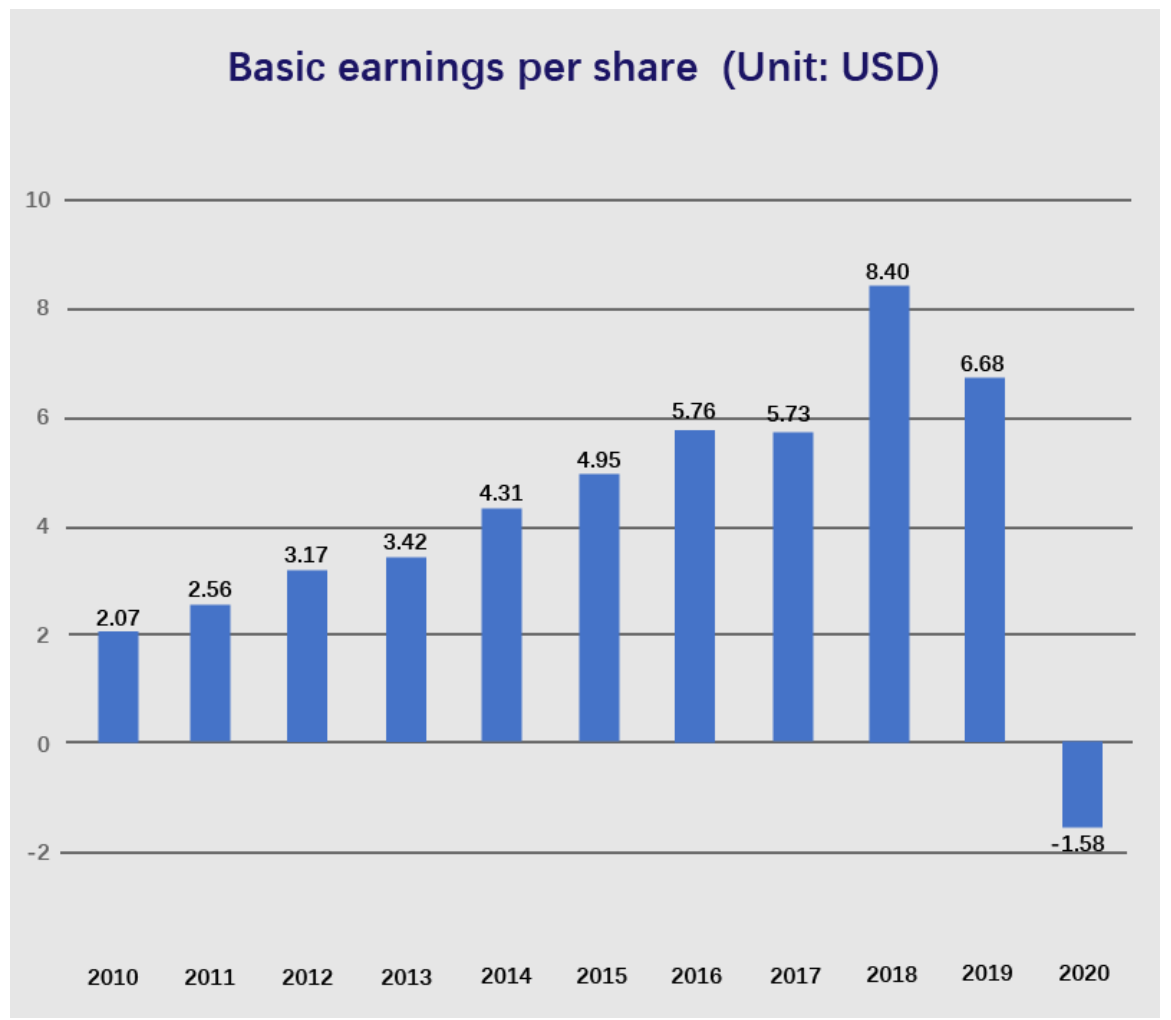

Figure 4 Earnings per share form 2010 to 2020.

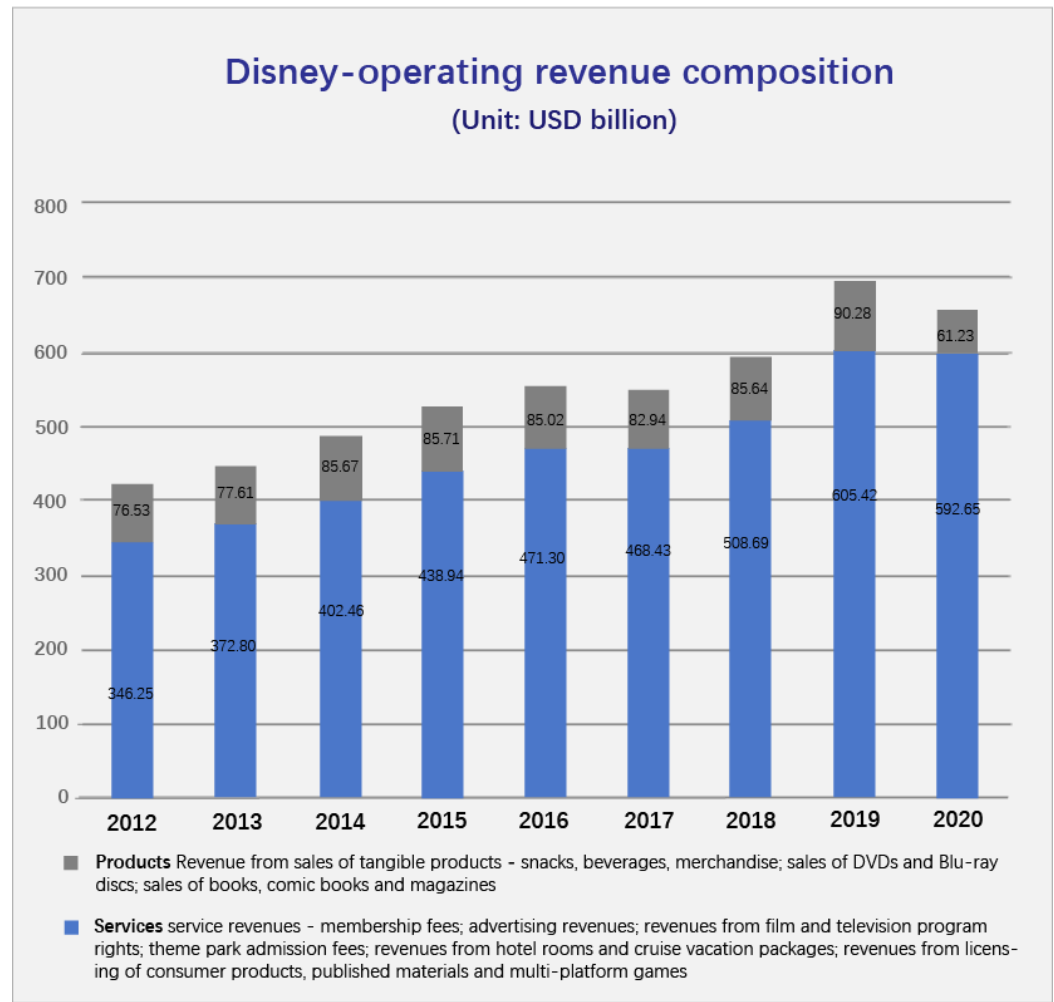

Figure 5 The different revenue scenarios of Disney-products \& services. 


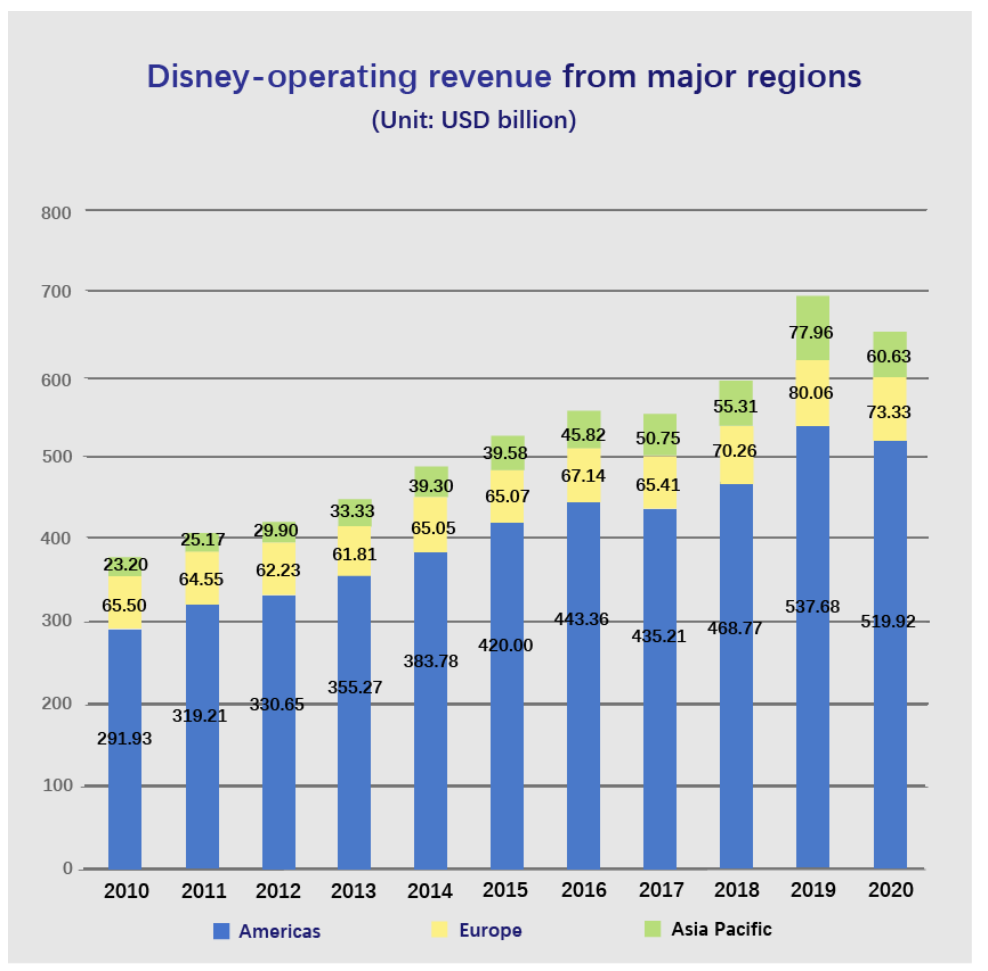

Figure 6 Total revenue of Disney in different regions.

\subsection{The Economic Situation of the Four Parts of Disney}

From the overall trend, due to the epidemic, the theme park profits were more affected, falling to negative, which had a huge impact on all of Disney's interests. The media network became a
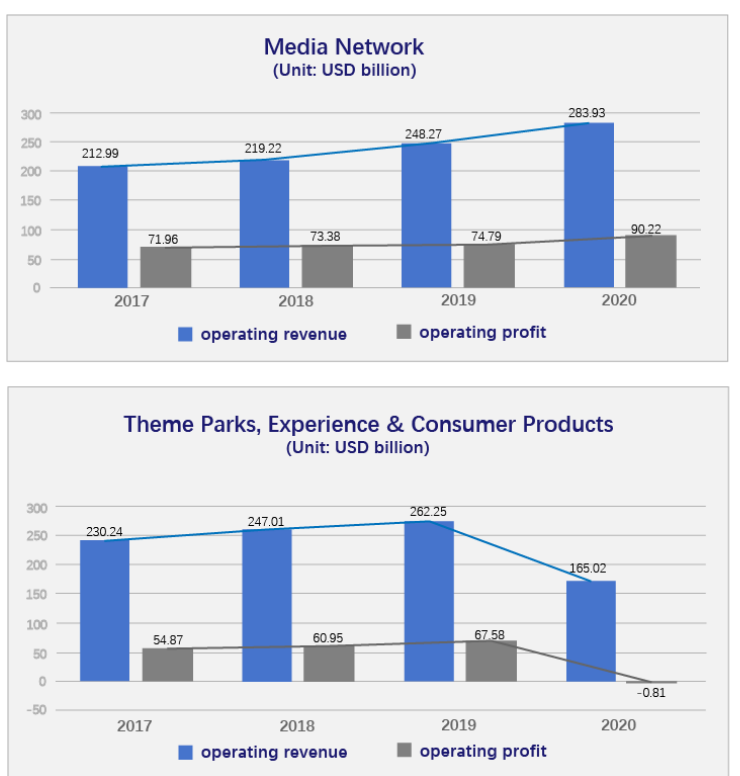

Figure 7 The economics of the four parts of Disney [7]. new interest driver, becoming the only growth segment among the four components.

If not for the impact of the epidemic, perhaps Disney's theme park fees would also have become the most dominant economic source.

Most of the decline in Disney's revenue came from a significant decline in theme parks.
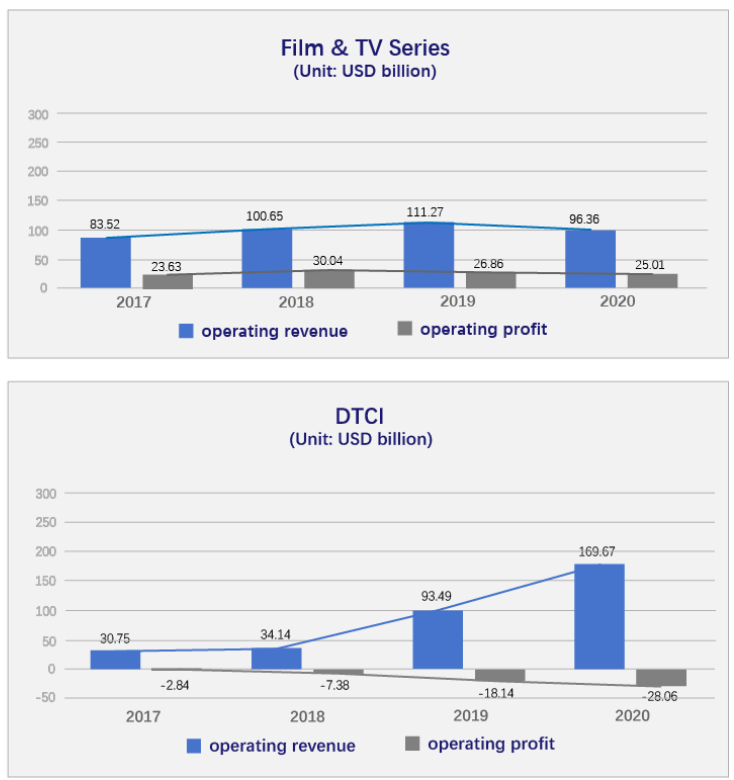
The data show that it is still the Disney-related service industry that accounts for the vast majority of the revenue components.

The decision to invest more in the media network during the epidemic was the right one, while DTCI was the segment that grew faster due to its impact. Disney's economy has its own independent development in different directions, and to some extent this has greatly mitigated the impact of the epidemic on Disney.

\section{OPINIONS ON THE DEVELOPMENT OF DISNEY THEME PARKS BASED ON CUSTOMER REVIEWS}

\subsection{Grouping}

We obtained a dataset of three Disney amusement parks (Asia, Europe and America) from 2014-2019. The data set is grouped and counted by rating, with a total of 5 groups (higher scores indicate that the customer feels more satisfied)

Table 1. Statistics on Rating

\begin{tabular}{l|l}
\hline Rating & Review_Text \\
\hline 1 & 1499 \\
\hline 2 & 2127 \\
\hline 3 & 5109 \\
\hline 4 & 10775 \\
\hline 5 & 23146 \\
\hline
\end{tabular}

From Table 1, we can know that visitors to Disneyland's overall evaluation is still good, fivestar rating accounted for about 54.26\%; one-star and two-star accounted for a total of $8.5 \%$, which shows that most visitors are still satisfied with the experience.

\subsection{Word Cloud - Data Visualization [9]}

Words rating=1 and rating=2 have a larger proportion of negative words (disappointed), but the proportion of positive words starts to increase from rating=3 (fantasyland, attract).

From this we can also get the reasons why visitors give different ratings. It is clear from this that most of the reasons for the low rating are because of the long waiting time, price, queues, etc. And the reasons for the high rating are because of the fireworks, the atmosphere created by some special holidays (such as Halloween, Thanksgiving, Christmas, etc.) that make the experience satisfying, and people choose to visit Disney on these special holidays. The fact that there are more people out with their families (especially with their daughters), Disney is a child's paradise, and the princesses and fireworks are very appealing to children (which especially attracts girls). Also, maybe some couples like to date at Disney.

If Disney wants to improve its reputation and visibility, perhaps it needs to pay more attention to dining (price and variety, value for money, etc.) and service (ticketing, etc.). On top of that continue to keep in the continuation of their own unique culture, and even make innovations in fireworks and themed rides. 


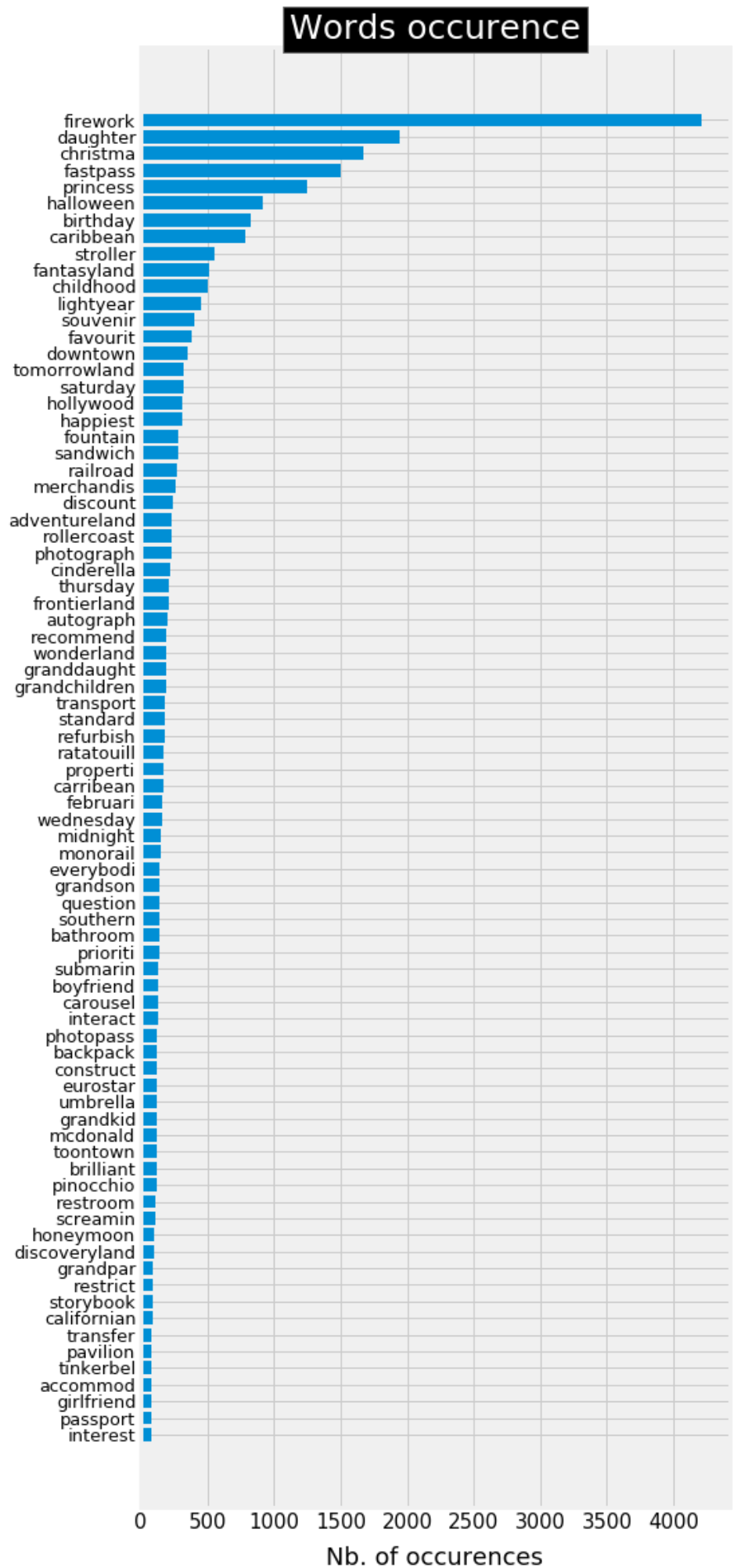

Figure 8 (Rating=5 for example) [8]. 

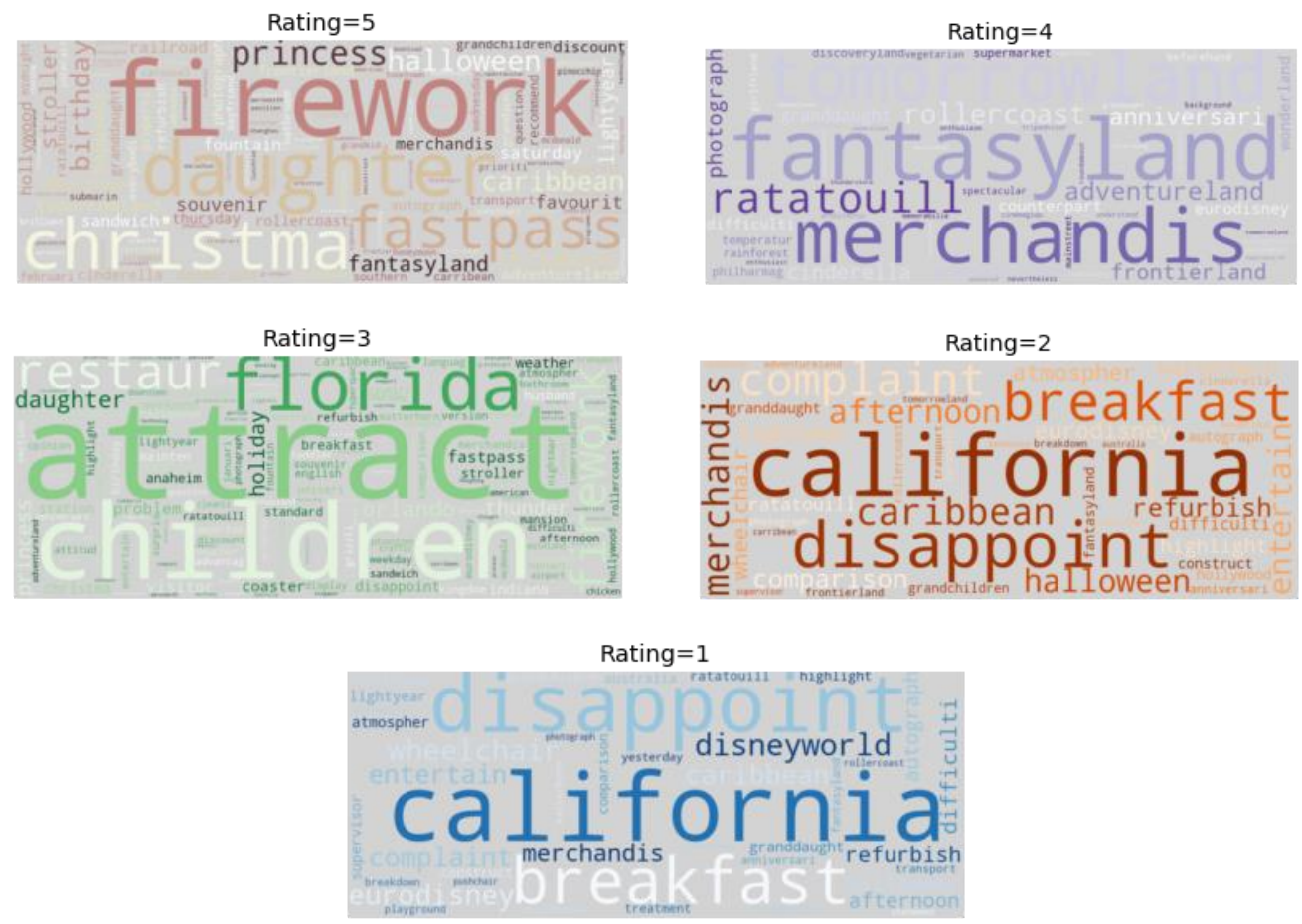

Figure 9 Cloud charts of different Ratings [10]

\section{CONCLUSION}

Hit by the epidemic, Disney's overall economic situation is not optimistic, the media network is currently the only revenue growth segment of Disney, Disney can continue to consider the development of this module in the long term to broaden revenue channels (this is due to the uncertainty of theme park revenue, however theme parks should have been the main source of revenue).

The most outstanding feature of Disney as a century-old company lies in its continuous innovation, constantly breaking the original inherent model, expanding new economic development modules, and combining its advantages with current hot topics, which brings inspiration to traditional media. But at the same time, this business model of Disney is very unique and may not be imitable, first of all, few media industries have such a large and long-lasting IP image of influence.

For the future development assessment exclusively from customer reviews is limited, the text only selected the reviews of one park in each state, there may be data bias (in different places based on local characteristics Disney may provide different services). Secondly, the reviews can only predict the future under the existing model, and there is no control over the emergence of new things, for example, with the emergence of new IPs, visitors may ignore the service quality when doing the evaluation. Finally, it is not possible to exclude that the evaluation will decrease with the number of times.

At this time, it appears that due to the impact of the outbreak and based on the fact that the outbreak is not going away anytime soon, the best course of action for Disney at this time is to continue to develop the online media and DCTI segments. At the same time, increase sales of Disneyland in China (where the outbreak is under control). It is foreseeable that when the epidemic is no longer a concern, Disneyland will see a significant increase in revenue, and at that time, if a new bright spot emerges, it will have unexpected economic effects.

\section{AUTHORS' CONTRIBUTIONS}

This paper is independently completed by Siping Ren.

\section{ACKNOWLEDGMENTS}

First of all, I would like to show you my sincere gratitude to my teachers and professors who have been very patient in teaching me knowledge and 
have been a bright light on my path of study. My university, which provided me with a broad learning platform, gave me access to the most cutting-edge knowledge and allowed me to listen to the experiences imparted by the bigwigs from the academic world, all of which will become valuable assets on my way to growth. Finally, I would like to thank my best friends and roommates for their encouragement and support, which has made me who I am now. I don't know how to say this, but I would like to say that I have completed my dissertation.

\section{REFERENCES}

[1] Cai Qingbai. Strategic financial analysis of Disney and Time Warner [D]. Xiamen University, 2019.

[2] Zhao Xinli. Content strategy and marketing strategy of media convergence--the practice of Disney Group as an example [J]. Young Journalists, 2020(25):60-61.

[3] Li Y. Disney's online video development strategy and inspiration $[\mathrm{J}]$. Audiovisual World, 2021(01):99-103.

[4] Yan Haitao. The success of Disney's industrialized operation $[\mathrm{J}]$. Media, 2020(15):48-50.

[5] Rong, Li-Ming. Application of text mining in e-commerce review analysis [D]. Huazhong University of Science and Technology, 2016.

[6] $\mathrm{Wu}$ Zhongqiang. Research on text mining based microblog event analysis method [D]. Nanjing University, 2018.

[7] Disney's theme park ringgit in fiscal quarter [J]. China and foreign toy manufacturing, 2020(12):78

[8] Wang Yakun. Research on social media text analysis methods based on machine learning [D]. Beijing University of Posts and Telecommunications, 2019.

[9] Xu Jin. Research on visual analysis methods for comment data [D]. Zhejiang University, 2018.

[10] Disney (DIS) Annual Report Link: https://www.sec.gov/cgi-bin/browseedgar?action $=$ getcompany $\&$ CIK $=0001744489$ \&type $=10$ -

K\&dateb $=\&$ owner $=$ include $\&$ count $=100$ 